Research Article

\title{
Determinants of the Intention of Social Aid Beneficiaries to Use Banking Self-Service Technology (SST)
}

\author{
Faizatul Hiqmah* \\ Department of Management, STIE Perbanas Surabaya, Jl. Wonorejo Utara 16 Rungkut, Surabaya, East Java 60296, Indonesia
}

\section{ARTICLE INFO}

\section{Article History}

Received 10 January 2021

Accepted 10 February 2021

Keywords

Self-Service Technology (SST)

banking

social aid beneficiaries

social contagion

\begin{abstract}
This study aims to examine the intention of social aid beneficiaries to use banking Self-Service Technology (SST). In general, the social aid beneficiaries have limitations in accessing banking technologies. Therefore, research on the determinants of the intention of social aid beneficiaries in using banking SST is considered necessary. The independent variables used in this study are attitude, coercive pressure, normative pressure, mimetic pressure, and perceived costs, while the dependent variable is the intention to use banking SST. Respondents in this study are social aid beneficiaries who have used banking services. The research hypotheses are tested using Partial Least Square-Structural Equation Model (PLS-SEM) analysis with WarpPLS 7. The results of this study indicate that attitude, normative pressure, mimetic pressure, and perceived costs have a significant positive effect on the intention to use banking SST, while coercive pressure has a significant negative effect on the intention to use banking SST.
\end{abstract}

(C) 2021 The Author. Published by Atlantis Press International B.V. This is an open access article distributed under the CC BY-NC 4.0 license (http://creativecommons.org/licenses/by-nc/4.0/).

\section{INTRODUCTION}

Technology adoption has become a major concern for several industries, including banking, due to the fact that even though the technology is increasingly advanced and the public access to the technology is getting higher, the uptake of banking technology adoption has grown quite low [1]. At the global level, only about $15 \%$ of bank customers use mobile devices to manage bankingrelated transactions, comprising $17 \%$ in North America, $22 \%$ in Latin America, $16 \%$ in Europe, $2 \%$ in Asian newly developed countries, $24 \%$ in Asian developed countries, and $11 \%$ in the Middle East and North Africa [1].

Banking industry is one of the leading sectors in offering SelfService Technology (SST). In particular, the development of SST in the banking world includes the use of service-based technology, such as ATM machines, online banking, and mobile banking. Previous research related to the adoption of banking SST tended to use behavioral perspective $[2,3]$ and trust perspective [4,5]. Meanwhile, the use of social perspective in seeing the adoption of SST is still rare and fragmented [1].

This study tries to integrate several models, such as attitude perspective, social perspective, perceived costs, and social interaction perspective in the adoption of SST. In particular, this study discusses the intention of social aid beneficiaries to use banking SST, under the title "Determinants of the intention of social aid beneficiaries to use banking self-service technology (SST)".

"Email: faizatul@perbanas.ac.id

\section{THEORITICAL BASIS}

\subsection{Attitude}

In general, attitude is defined as a psychological tendency which is expressed by evaluating certain entities with the degree of "like or dislike" [6]. In accordance with the context conducted in this study, attitudes toward SST refer to the social aid beneficiaries' degree of "like or dislike" in using SST. Many studies in social psychology and marketing support the role of attitude in predicting the intention to behave [7-10]. In addition, the relationship between attitudes and desires to adopt is also found in other areas of research $[2,11]$.

Several studies suggest that attitudes emerge and influence behavior in a sequential process [12]. Related to the formation of attitudes and changes, some literature states that there is a transfer of attitudes from one entity to another. For example, research on advertising shows that attitude toward advertising influence attitude toward brands $[13,14]$.

Adoption is attached to attitude as one of its formers [15]. Related to research on the adoption of new banking channels, developed a model which states that the behavior of adopting more recent channels, by those who have used SST channels before, influences the desire of new users to adopt the SST behavior [2]. While other researcher stated that the "halo effect" is very likely to occur when there is a positive evaluation of one technology channel that will affect other technology channels [16].

Previous research mentions the existence of channeling attitudes in a multi-channel context. A study conducted by explores the factors 
that influence a person's choice of banking channels [17]. The study found that knowledge and views of channel convenience (ATM and online) strongly influence preferences for using traditional channels. A qualitative study conducted by another researcher proposed a concept that investigates how attitudes in using technology in general and attitudes toward SST channels shape attitudes in using certain SSTs. In contrast, another study found that attitudes toward certain bank channels determine consumer attitudes toward banks and SST as a whole, which have an impact on perceived enjoyment, utility and social acceptance [2]. While another research show that sociodemographic characteristics and perceptions of traditional bank channels affect the sustainability of online banking use [18]. This indicates that consumers may have intention to adopt more advanced technology-based services, such as SST, as long as they show a positive attitude toward the technology-based services. In accordance with the explanation above, the first hypothesis is formulated as follows:

H1: Attitude has a direct effect on the intention to adopt SST

\subsection{Coercive Pressure}

Coercive pressure refers to changes in individual behavior caused by the orders of stronger social actors [19]. Communities or individuals have no other choice but to demonstrate the behavior desired by entities with more power [3]. For example, banks or government agencies require people to use certain channels (mobile banking) to carry out certain activities, such as electricity payments. Therefore, someone tends to adopt a new technology as a form of obedience to entities that have more power. In this regard, the second hypothesis is formulated as follows:

H2: Coercive pressure has a direct effect on the intention to adopt SST

\subsection{Normative Pressure}

Normative pressure refers to changes in a person's behavior as a result of his unconscious desire to conform to social norms when certain behavior becomes behavior that is considered normal or popular among relatives or society [20]. Meanwhile, people who do not follow this behavior will experience frustration and discomfort because they are considered to be left behind by people who have adopted this new behavior [3]. Most consumers are motivated by the desire to conform to the standards of behavior shown by the wider community [20]. Therefore, people generally adopt a new technology to adapt to their environment. So, the third hypothesis is formulated as follows:

H3: Normative pressure has a direct effect on the intention to adopt SST

\subsection{Mimetic Pressure}

Mimetic pressure refers to actions taken voluntarily and consciously to mimic the same behavior shown by those who are considered more successful and have higher status [3]. The mimetic effect in the context of the adoption of innovation is a catalyst or link for the non-adopter community to believe more that the action must be done because someone else has done it [21]. Research states that people have a tendency to mimic the behavior of other individuals of higher status who have adopted previous technology as a way to express themselves and improve their self-image [22]. People often believe that if they adopt a technology, other people will like them or they will be able to interact with other individuals [22]. Therefore, individuals who are driven by mimetic pressure will adopt SST when they see that those who are popular, admired, and respected are also adopting the technology [1]. Based on the explanation above, the fourth hypothesis is formulated as follows:

H4: Mimetic pressure has a direct effect on the intention to adopt SST

\subsection{Perceived Cost}

One of the barriers to use new technology is the cost of obtaining the technology and for its use [23]. Previous research indicated that the perceived cost would be a major barrier to the adoption of certain SST channels $[24,25]$. Other studies have found that there is a negative relationship between perceived costs and the intention to use m-banking [26], where the more the cost of using new technology, the lower the intention to use it. In accordance with the description above, the fifth hypothesis is formulated as follows:

H5: Perceived cost has a direct influence on the intention to use SST

\section{RESEARCH METHOD}

\subsection{Conceptual Framework}

Based on the hypotheses presented above, the conceptual framework is shown on Figure 1. As seen in Figure 1, the variables in this study consist of five independent variables (attitude, coercive pressure, normative pressure, mimetic pressure and perceived costs) and one dependent variable (the intention to use SST). Each variable is measured by several items adapted from previous research. The items in this questionnaire are measured using a 5 Likert Scale ranging from Strongly Disagree (1) to Strongly Agree (5).

\subsection{Operational Definition of Variables}

Measurements of attitude, coercive pressure, mimetic pressure, normative pressure, and the intention to use SST channels and measurement of perceived cost are adapted from previous research

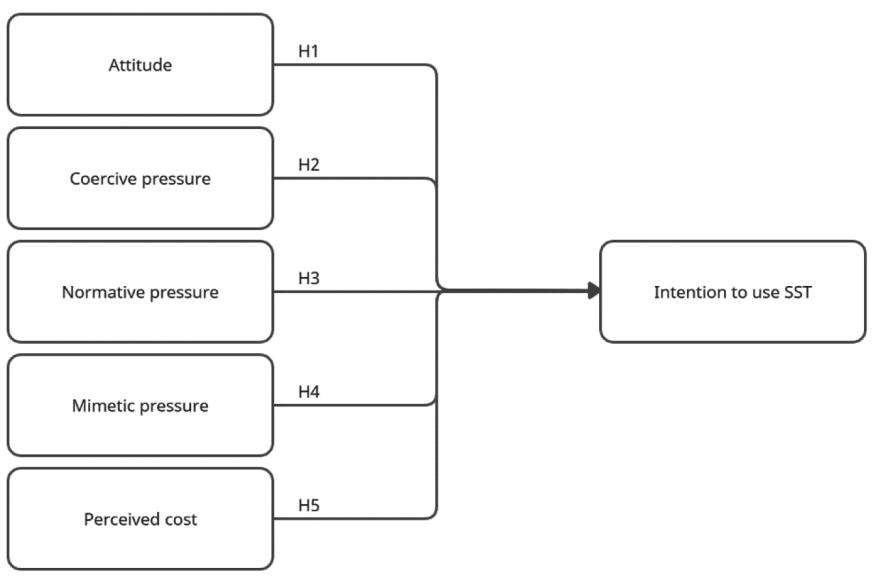

Figure 1 Research framework. 
Table 1 Operational definitions and questionnaire statements

\begin{tabular}{|c|c|c|c|}
\hline Variables & Operational definition & Questionnaire statement & Item \\
\hline \multirow[t]{2}{*}{ Attitudes (ATT) [1] } & \multirow[t]{2}{*}{$\begin{array}{l}\text { Evaluation (like or dislike) of banking } \\
\text { transactions carried out }\end{array}$} & $\begin{array}{l}\text { In my opinion, aid distribution through banking } \\
\text { transactions is very pleasant }\end{array}$ & ATT1 \\
\hline & & I like doing banking transactions & ATT2 \\
\hline \multirow[t]{3}{*}{$\begin{array}{l}\text { Coercive Pressure } \\
\text { (COP) [1] }\end{array}$} & \multirow[t]{3}{*}{$\begin{array}{l}\text { The need to use banking services by more } \\
\text { powerful social actors }\end{array}$} & $\begin{array}{l}\text { Many of my financial matters require the use of } \\
\text { banking transactions }\end{array}$ & COP1 \\
\hline & & $\begin{array}{l}\text { Many financial transactions can only be done through } \\
\text { banking transactions }\end{array}$ & $\mathrm{COP} 2$ \\
\hline & & $\begin{array}{l}\text { My financial interactions with work and my colleagues } \\
\text { have forced me to do banking transactions }\end{array}$ & COP3 \\
\hline \multirow{3}{*}{$\begin{array}{l}\text { Normative Pressure } \\
\quad(\mathrm{NOP})[1]\end{array}$} & \multirow{3}{*}{$\begin{array}{l}\text { Unconscious desire to adapt to an environment that } \\
\text { shows the use of banking transactions }\end{array}$} & I see many people who do banking transactions & NOP1 \\
\hline & & $\begin{array}{l}\text { Many people in my surroundings do banking } \\
\text { transactions }\end{array}$ & NOP2 \\
\hline & & $\begin{array}{l}\text { I can easily see the use of banking transactions in my } \\
\text { social environment }\end{array}$ & NOP3 \\
\hline \multirow[t]{2}{*}{ Mimetic Pressure (MIP) } & \multirow[t]{2}{*}{$\begin{array}{l}\text { Voluntary action to conduct banking transactions as } \\
\text { done by people who are considered to have a higher } \\
\text { social strata }\end{array}$} & $\begin{array}{l}\text { People around me who do banking transactions are } \\
\text { more authoritative than those who do not do } \\
\text { banking transactions }\end{array}$ & MIP1 \\
\hline & & $\begin{array}{l}\text { The use of banking transactions is a measure of social } \\
\text { status in my community }\end{array}$ & MIP2 \\
\hline \multirow[t]{2}{*}{ Perceived Costs (PC) [23] } & \multirow{2}{*}{$\begin{array}{l}\text { Perceived costs that need to be incurred to conduct } \\
\text { banking transactions }\end{array}$} & Doing banking transactions requires a lot of fees & $\mathrm{PC} 1$ \\
\hline & & $\begin{array}{l}\text { I feel that the fees I have to pay for banking transactions } \\
\text { are quite high }\end{array}$ & PC2 \\
\hline $\begin{array}{l}\text { The Intention to use (INT) } \\
\text { banking services [1] }\end{array}$ & The intention to use banking SST & $\begin{array}{l}\text { I think I will use banking transactions for my financial } \\
\text { affairs in addition to withdrawing social assistance }\end{array}$ & INT1 \\
\hline
\end{tabular}

Source: Chaouali and El Hedhli [1], Hanafizadeh et al. [23].

$[1,23]$. The operational definition and questionnaire statement for the items developed are structured in Table 1.

\subsection{Data Collection}

Data collection in the study is carried out by conducting direct surveys by distributing questionnaires to respondents. The respondents in this study are social aid beneficiaries who have used banking services. Of the 220 questionnaires distributed, only 200 questionnaires can be used for further hypothesis testing. The questionnaire distribution process was carried out from January to April 2019. Respondents in this study are classified according to age, latest education, length of time receiving social assistance, and the type of banking services used, as presented in Table 2.

\section{DATA ANALYSIS}

This study uses the Partial Least Square (PLS)-SEM method to test the proposed models. PLS-SEM has attracted the attention of researchers because its latent variable modeling technique is able to accommodate various dependent constructs and contains clear error sizes [27]. The latest evidence also shows that PLS-SEM is a powerful method in estimating models and is considered more capable of constructing validity than covariance based-structural equation modeling (CB-SEM) [28,29].

\subsection{Model Measurement}

Model evaluation in SEM-PLS is carried out using the WarpPLS 7.0 program by testing the outer model and the inner model.
Table 2 Characteristics of respondents

\begin{tabular}{llcc}
\hline Size & Item & Number & Percentage (\%) \\
\hline Gender & Female & 200 & 100 \\
& Male & 0 & 0 \\
Age (years) & $20-38$ & 54 & 27 \\
& $39-55$ & 132 & 66 \\
Education & $>55$ & 14 & 7 \\
& Never attended school & 17 & 8 \\
& Elementary school & 105 & 52 \\
& Junior high school & 51 & 26 \\
Length of time & Senior high school & 25 & 13 \\
receiving social & Associate's degree & 2 & 1 \\
assistance & 1-2 year & 14 & 7 \\
Length of time & $>2$ years & 11 & 5 \\
using banking & 1 year & 175 & 88 \\
services & $>2$ years & 14 & 7 \\
\hline
\end{tabular}

Source: Research results (2019).

Evaluation of the measurement model or outer model is carried out to define the relationship between latent variables and their forming indicators. Tests conducted to evaluate the outer model are convergent validity, discriminant validity, and reliability tests.

\subsection{Convergent Validity Test}

The convergent validity test is used to ensure that the items used in the questionnaire effectively reflect the factors in question [30]. This test shows the degree to which a factor is positively correlated with other factors for the same construct [29]. In SEM, convergent validity can be seen through the loading value, Composite 
Reliability (CR) value, and Average Variance Extracted (AVE) value. In addition, the loading value of each item must also be high and statistically significant to be able to measure the construct in question. The loading value of each item is at least 0.5 , while the AVE and CR values should not be below 0.5 and 0.7 respectively. Therefore, items or indicators that have a value below 0.5 will be eliminated while those with a value above 0.5 will be maintained to obtain the desired AVE and composite reliability values in this study [31].

Reliability test is done by looking at the composite reliability value. Composite reliability is considered to be more able to explain constructs in a reflective model than Cronbach alpha [32]. Cronbach alpha reliability is considered to have an over or under-estimate reliability scale [32]. In this regard, the composite reliability value is considered more capable of presenting a higher estimate of the reliability of measuring instruments [32]. For an exploratory research model, the composite reliability value must be $>0.6[33,34]$. Meanwhile, for the confirmatory model, the composite reliability value is $>0.7$ [35].

The results of the convergent validity test, as part of the outer model test consisting of the loading value, composite reliability value, and AVE value, are presented in Table 3.

From the results of the Outer Model Test in Table 3, it can be seen that the loading value shown by each construct is $>0.5$, the composite reliability value shown by each variable is $>0.7$, and the AVE value is also $>0.5$. It can be concluded that the constructs used in this study are reliable.

\subsection{Discriminant Validity Test}

Discriminant validity indicates whether the tested factors are statistically different. This test shows the degree to which one construct differs from another based on the empirical measure [29]. Therefore, the items of a certain construct must have variation among them, exceeding variation with other variables. The discriminant validity test can be done using the root comparison of the AVE with the correlation between variables. The AVE construct value should be higher than the correlation between latent variables [36]. The calculation result of WarpPLS 7.0 shows that the root value of AVE for the same variables is higher than the root

Table 3 Outer model test results

\begin{tabular}{llccc}
\hline Factors & Item & Loading & CR & AVE \\
\hline Attitude (ATT) & ATT1 & 0.897 & 0.892 & 0.805 \\
Coercive Pressure (COP) & COT2 & 0.897 & & \\
& COP2 & 0.904 & & \\
& COP3 & 0.778 & & \\
Normative Pressure (NOP) & NOP1 & 0.913 & 0.941 & 0.841 \\
& NOP2 & 0.924 & & \\
Mimetic Pressure (MIP) & NOP3 & 0.914 & & \\
& MIP1 & 0.785 & 0.763 & 0.617 \\
Perceived Costs (PC) & MIP2 & 0.785 & & \\
Intention to use (INT) & PC1 & 0.892 & 0.886 & 0.796 \\
& PC2 & 0.892 & & \multirow{2}{*}{0.829} \\
& INT1 & 0.789 & 0.767 & 0.622 \\
\hline
\end{tabular}

Source: Research results (2019). value of AVE for different variables. This shows that the criteria for the discriminant validity test have been met. As shown in Table 4, the AVE construct value is higher than the correlation between other latent variables, so that the discriminant validity test in this study is declared fulfilled.

\subsection{Structural Model (Inner Model) and Hypothesis Testing}

The structural model test is carried out by conducting path analysis using the WarpPLS 7.0 software (ScriptWarp Systems, Laredo, TX, USA). The path analysis model is described in Figure 2.

The predictive relevance test of the model is done by looking at the $R 2$ value. $R 2$ is used to determine the degree of variance of endogenous variables explained by exogenous variables [33]. The $\mathrm{R} 2$ value for the intention to use SST in this study is indicated by a value of 0.44 which indicates that the research model is able to provide a reasoned explanation to explain the behavior of the social aid beneficiaries.

To evaluate the structural relationship between latent variables, hypothesis testing must be carried out on the path coefficient between the variables by comparing the $p$-value with 0.05 . The amount of $p$-value is obtained at the output of WarpPLS 7.0. Testing all hypotheses will be analyzed based on the results obtained from data processing as shown in Table 5.

Table 4 Discriminant validity test results

\begin{tabular}{lcccccc}
\hline Variables & ATT & COP & NOP & MIP & PC & INT \\
\hline ATT & $(0.897)$ & 0.115 & 0.082 & -0.205 & 0.061 & 0.059 \\
COP & 0.115 & $(0.873)$ & 0.459 & -0.510 & 0.128 & -0.178 \\
NOP & 0.082 & 0.459 & $(0.917)$ & -0.527 & 0.188 & 0.102 \\
MIP & -0.205 & -0.510 & -0.527 & $(0.785)$ & -0.196 & 0.112 \\
PC & 0.061 & 0.128 & 0.188 & -0.196 & $(0.892)$ & 0.063 \\
INT & 0.059 & -0.178 & 0.102 & 0.112 & 0.063 & $(0.789)$ \\
\hline
\end{tabular}

Source: Research results (2019).

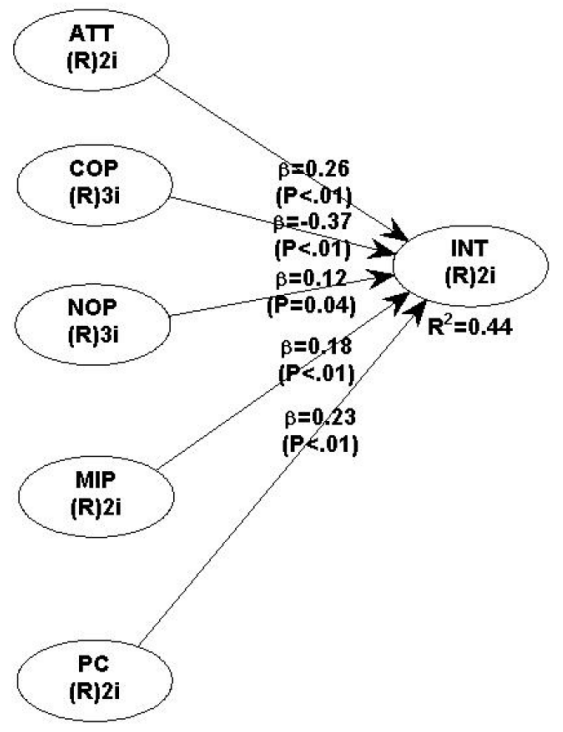

Figure 2 Inner model test results. Source: Research results (2019). 
Table 5 Path coefficient test results

\begin{tabular}{lccrl}
\hline Hypotheses & Paths & Path coefficient & $\boldsymbol{p}$-values & Conclusion \\
\hline H1 & ATT $\rightarrow$ INT & 0.262 & $<0.001$ & H1 is accepted \\
H2 & COP $\rightarrow$ INT & -0.366 & $<0.001$ & H2 is accepted \\
H3 & NOP $\rightarrow$ INT & 0.125 & 0.036 & H3 is accepted \\
H4 & MIP $\rightarrow$ INT & 0.184 & 0.004 & H4 is accepted \\
H5 & PC $\rightarrow$ INT & 0.226 & $<0.001$ & H5 is accepted \\
\hline
\end{tabular}

Source: Research results (2019).

Figure 2 and Table 5 show the results of the structural model test. Specifically, the results obtained show that (1) attitude $(b=0.262$, $p<0.001)$ has a significant positive effect on the intention to use SST, (2) coercive pressure $(b=-0.366, p=<0.001)$ has a significant negative effect on the intention to use SST, (3) normative pressure ( $b=0.125, p=0.036)$ has a significant positive effect on the intention to use SST, (4) mimetic pressure $(b=0.184, p=0.004)$ has a significant positive effect on the intention to use SST, and (5) perceived cost $(b=0.226, p<0.001)$ has a significant positive effect on the intention to use SST. These results indicate that $\mathrm{H} 1, \mathrm{H} 2, \mathrm{H} 3$, $\mathrm{H} 4$, and $\mathrm{H} 5$ are confirmed to be accepted.

\section{DISCUSSION OF FINDING}

The main objective of this study is to conduct a critical test of the factors that influence the intention of social aid beneficiaries to use SST further. In particular, this study looks at what factors that influence the intention of social aid beneficiaries to use banking services other than account ownership and use of debit cards for the aid withdrawal. The results of this study indicate that all the variables tested have a direct influence on the intention to use SST.

The results of previous research [1] show that attitude, trust, and social contagion (consisting of coercive pressure, normative pressure, and mimetic pressure) have a significant positive influence on the intention to use technology-based banking services. This study also uses the same variable model to test whether attitude and social contagion experienced by social aid beneficiaries also have an influence on the intention to use banking services.

The results of this study indicate that the social aid beneficiaries' attitude toward banking services has a significant positive effect on the intention to use banking services ( $\mathrm{H} 1)$. This finding is in line with the previous research [1] where attitudes toward ATMs are able to predict the intention to adopt the intention to use online banking. The findings in this study also confirm that attitudes toward banking services are able to predict the intention to use other banking services [1].

Social contagion is a study which states that the individual's intention to behave is also driven by social forces consisting of coercive pressure, normative pressure, and mimetic pressure. Social contagion theory states that individuals adopt something new (products, services, technology, etc.) either compulsively because they have to adjust to the regulations of those who are considered powerful (for example: service providers, suppliers, and public authorities) or voluntarily through learning and positive reinforcement [22].

The results of this study indicate that coercive pressure has a significant negative effect on the intention to use banking services (H2), normative pressure has a significant positive effect on the intention to use banking services $(\mathrm{H} 3)$, and mimetic pressure has a significant positive effect on the intention to use banking services (H4).

The first dimension of social contagion in this study is coercive pressure. Coercive pressure has a significant negative effect on the intention to use banking services (H2). The higher the coercive pressure, the lower the intention to use banking services. The results of this study contradict the previous study [1] where coercive pressure has a significant positive effect on the intention to adopt banking SST. This difference in findings is caused by the difference in research objects. In previous research [1], the research objects are the people who have been familiar with banking services, although they still consider that mobile banking technology is something new, while in this study, the research objects are the social aid beneficiaries who psychographically are the middle to lower class society, or when viewed from their work, it does not require them to use banking services. The majority of respondents in this study only use banking services for the purpose of obtaining social assistance.

The second dimension of social contagion in this study is normative pressure. Normative pressure has a significant positive effect on the intention to use banking services (H3). This means that the higher the normative pressure in society, the higher the impact on the intention of social aid beneficiaries to use banking services. This finding is in accordance with the previous study [1] that normative pressure has a significant positive effect on the intention to use banking services.

The last dimension of social contagion in this study is mimetic pressure. The test result conducted by using WarpPLS shows that mimetic pressure has a significant positive effect on the intention to use banking services (H4). The result of this study is in accordance with the results of previous research [1] where mimetic pressure has a significant positive effect on the intention to use mobile banking services. The results obtained from the tests conducted show that the higher the value of mimetic pressure, the higher the intention to use banking services. The mimetic pressure itself in this study is expressed by the perceived social status a person gets when using banking services.

The variable of perceived costs has a significant positive effect on the intention to use banking services (H5). This means that the higher the perceived costs that must be incurred for conducting banking transactions, the higher the intention to use banking services. This is because the social aid beneficiaries think that the use of banking services does require fees, and when they have the funds, they will be willing to spend it for better banking services. However, this finding is not in accordance with the results of previous research [23] where the higher the perceived costs involved in obtaining the latest technology, the lower the intention to use banking technology.

\section{CONCLUSION}

\subsection{Summary of Research Finding}

The results of this study indicate that attitude, normative pressure, mimetic pressure, and perceived costs have a significant positive effect on the social aid beneficiaries' intention to use banking SST, 
while coercive pressure has a significant negative effect on the social aid beneficiaries' intention to use banking SST.

The results of this study shows that people receiving social assistance, regardless of their economic conditions, have a tendency to adopt banking service technology further. The social aid beneficiaries generally only use banking services in the form of accounts and ATMs that are withdrawn through stalls designated by the authority to carry out banking activities, in this case the withdrawal of social assistance. These also indicate that the social aid beneficiaries have an intention to use other banking service technologies, apart from those they usually use to take social assistance, due to the driving factors, such as their attitude toward banking services, coercive pressure, normative pressure, mimetic pressure, as well as perceived costs they have to spend to carry out banking activities.

\subsection{Contribution to the Literature}

This study has a significant theoretical contribution because the research subjects are the social aid beneficiaries who have rarely been studied before. The social aid beneficiaries are a fairly large group of people and have become the main target of a country's financial inclusion targets. In addition, the results of the variables tested in this study indicate that there are differences in behavior between people who are familiar with banking services and people who only use banking services as a means of obtaining social assistance only.

\subsection{Practical Implications}

The findings in this study have several practical implications that can be used as reference for the government, financial services authorities, and banks in particular. This study reveals several factors that have an important influence on the intention of the social aid beneficiaries to use banking services further. The results of this study can be used by the competent authorities to support decision-making, especially to encourage wider banking and financial access for the whole Indonesian people.

\subsection{Limitations}

Despite optimal efforts, there are still limitations in this study, such as the limitation of the area which only covers the research area, so that the results of this study cannot be generalized in a broader scope. In addition, it is necessary to explore the use of other variables in the model, other than those used in this research, so that it can enrich the study of the intention of the social aid beneficiaries to further use technology-based banking services.

\subsection{Future Research Direction}

Current research urges the need for future studies to measure the level of social aid's beneficiaries' involvement as well. Since the level of social aid's beneficiaries involvement will also affect it's intention to adopt new technology (banking SST) [1]. Future studies can also broaden the scope of the variables that influence the intention to use banking SST in order to provide more comprehensive picture of the social aid's beneficiaries' intention to adopt SST.

\section{CONFLICTS OF INTEREST}

The author declares no conflicts of interest.

\section{REFERENCES}

[1] W. Chaouali, K. El Hedhli, Toward a contagion-based model of mobile banking adoption, Int. J. Bank Market. 37 (2019), 69-96.

[2] J.M. Curran, M.L. Meuter, Encouraging existing customers to switch to self-service technologies: put a little fun in their lives, J. Market. Theory Pract. 15 (2007), 283-298.

[3] W. Shi, N. Shambare, J. Wang, The adoption of internet banking: an institutional theory perspective, J. Financ. Serv. Market. 12 (2008), 272-286.

[4] H.H. Kuan, G.W. Bock, Trust transference in brick and click retailers: an investigation of the before-online-visit phase, Inform. Manage. 44 (2007), 175-187.

[5] X.L. Feng, L. Xu, Y. Guo, C. Ronsmans, Socioeconomic inequalities in hospital births in China between 1988 and 2008, Bull. World Health Organ. 89 (2011), 432-441.

[6] A.H. Eagly, S. Chaiken, The Psychology of Attitudes, Harcourt Brace Jovanovich College Publishers, Fort Worth, TX, 1993, p. 794.

[7] M. Fishbein, I. Ajzen, Belief, Attitude, Intention, and Behavior: An Introduction to Theory and Research, Addison-Wesley, Reading, MA, 1975, p. 578.

[8] S. Ha, L. Stoel, Consumer e-shopping acceptance: antecedents in a technology acceptance model, J. Bus. Res. 62 (2009), 565-571.

[9] A. Muk, C. Chung, Applying the technology acceptance model in a two-country study of SMS advertising, J. Bus. Res. 68 (2015), 1-6.

[10] L. Robinson, G.W. Marshall, M.B. Stamps, Sales force use of technology: antecedents to technology acceptance, J. Bus. Res. 58 (2005), 1623-1631.

[11] P.G. Schierz, O. Schilke, B.W. Wirtz, Understanding consumer acceptance of mobile payment services: an empirical analysis, Electron. Commer. Res. Appl. 9 (2010), 209-216.

[12] R.P. Bagozzi, On the neglect of volition in consumer research a critique and proposal, Psychol. Mark. 10 (1993), 215-237.

[13] A.A. Mitchell, J.C. Olson, Are product attribute beliefs the only mediator of advertising effects on brand attitude? J. Market. Res. 18 (1981), 318-332.

[14] S.B. MacKenzie, R.J. Lutz, G.E. Belch, The role of attitude toward the ad as a mediator of advertising effectiveness: a test of competing explanations, J. Market. Res. 23 (1986), 130-143.

[15] C. Xie, R.P. Bagozzi, S.V. Troye, Trying to prosume: toward a theory of consumers as co-creators of value, J. Acad. Market. Sci. 36 (2008), 109-122.

[16] J. Klein, N. Dawar, Corporate social responsibility and consumers' attributions and brand evaluations in a product-harm crisis, Int. J. Res. Market. 21 (2004), 203-217.

[17] J.G. Albesa, Interaction channel choice in a multichannel environment, an empirical study, Int. J. Bank Market. 25 (2007), 490-506.

[18] C. Flavián, M. Guinalíu, E. Torres, How bricks-and-mortar attributes affect online banking adoption, Int. J. Bank Market. 24 (2006), 406-423.

[19] S. Grob, S. Benn, Conceptualising the adoption of sustainable procurement: an institutional theory perspective, Australas. J. Environ. Manage. 21 (2014), 11-21.

[20] S.A. Sherer, C.D. Meyerhoefer, L. Peng, Applying institutional theory to the adoption of electronic health records in the U.S., Inform. Manage. 53 (2016), 570-580. 
[21] L.N. Tobey, C. Mouzong, J.S. Angulo, S. Bowman, M.M. Manore, How low-income mothers select and adapt recipes and implications for promoting healthy recipes online, Nutrients 11 (2019), 339.

[22] E.A. Walden, G.J. Browne, Sequential adoption theory: a theory for understanding herding behavior in early adoption of novel technologies, J. Assoc. Inform. Syst. 10 (2009), 31-62.

[23] P. Hanafizadeh, M. Behboudi, A.A. Koshksaray, M.J.S. Tabar, Mobile-banking adoption by Iranian bank clients, Telemat. Inform. 31 (2014), 62-78.

[24] T. Dahlberg, N. Mallat, J. Ondrus, A. Zmijewska, Past, present and future of mobile payments research: a literature review, Electron. Commer. Res. Appl. 7 (2008), 165-181.

[25] M. Kleijnen, K. de Ruyter, M. Wetzels, Consumer adoption of wireless services: discovering the rules, while playing the game, J. Interact. Market. 18 (2004), 51-61.

[26] L. Wessels, J. Drennan, An investigation of consumer acceptance of M-banking, Int. J. Bank Market. 28 (2010), 547-568.

[27] N.S.A. Karim, M.J.M. Razi, N. Mohamed, Measuring employee readiness for knowledge management using intention to be involved with KM SECI processes, Bus. Process Manage. J. 18 (2012), 777-791.

[28] W.M. Asyraf, B.W. Afthanorhan, A comparison of partial least square structural equation modeling (PLS-SEM) and covariance based structural equation modeling (CB-SEM) for confirmatory factor analysis, Int. J. Eng. Sci. Innov. Technol. 2 (2013), 198-205.
[29] J.F. Hair, M. Sarstedt, L. Hopkins, V.G. Kuppelwieser, Partial least squares structural equation modeling (PLS-SEM): an emerging tool in business research, Eur. Bus. Rev. 26 (2014), 106-121.

[30] T. Zhou, An empirical examination of continuance intention of mobile payment services, Decision Support Syst. 54 (2013), 1085-1091.

[31] L.A. Hayduk, L. Littvay, Should researchers use single indicators, best indicators, or multiple indicators in structural equation models? BMC Med. Res. Methodol. 12 (2012), 159.

[32] Garson GD, Statistical Publishing Associates, Asheboro, NC, USA, 2016.

[33] W.W. Chin, The partial least squares approach for structural equation modeling, in: G.A. Marcoulides (Ed.), Modern methods for business research, Lawrence Erlbaum Associates, Mahwah, NJ, 1998, pp. 295-336.

[34] C. Höck, C.M. Ringle, M. Sarstedt, Management of multi-purpose stadiums: importance and performance measurement of service interfaces, Int. J. Serv. Technol. Manage. 14 (2010), 188-207.

[35] J. Henseler, C.M. Ringle, M. Sarstedt, Using partial least squares path modeling in advertising research: basic concepts and recent issues, in: S. Okazaki, Handbook of Research on International Advertising, 2012, pp. 252-276.

[36] N. Kock, P. Hadaya, Minimum sample size estimation in PLSSEM: the inverse square root and gamma-exponential methods, Inform. Syst. J. 28 (2018), 227-261. 